\begin{tabular}{c} 
International Journal of Biological Research, 3(1)(2015) 36-41 \\
International Journal of Biological Research \\
SPC \\
Journal home page: $\begin{array}{c}\text { www.sciencepubco.com/index.php/IJBR } \\
\text { doi: } 10.14419 / \text { ijbr.v3i.4250 } \\
\text { Research Paper }\end{array}$ \\
\hline
\end{tabular}

\title{
Characterization of an alkaline protease with high quality bating potential in leather processing from Bacillus licheniformis MZK05M9 mutant
}

\author{
Md. Arafat Al Mamun ${ }^{1}$, Md. Murad Khan ${ }^{2}$, Md. Nahinur Rahman Akand ${ }^{2}$, \\ Shakila Nargis Khan ${ }^{2}$, Md. Mozammel Hoq ${ }^{2} *$ \\ ${ }^{1}$ Centre for Advanced Research in Sciences, University of Dhaka, Dhaka-1000, Bangladesh \\ ${ }^{2}$ Department of Microbiology, University of Dhaka, Dhaka-1000, Bangladesh \\ *Corresponding author E-mail: mhoq@du.ac.bd
}

\begin{abstract}
An alkaline protease from Bacillus licheniformis MZK05M9 (BlM9), a mutant strain developed in our laboratory, has been partially purified and characterized for its robustness and eco-friendly application potential in processing of hides and skins for leather manufacturing and detergent industries. The enzyme was purified 2.70 fold with specific activity of $1624 \mathrm{U} / \mathrm{mg}$ in comparison to crude enzyme extract by using ammonium sulfate precipitation, dialysis and Sephadex G-75 column chromatography. The molecular mass of the enzyme was $27.2 \mathrm{kDa}$ as judged by SDS-PAGE. The purified protease had a $\mathrm{pH}$ optimum of 8.5 and temperature optimum of $55^{\circ} \mathrm{C}$. According to the inhibition profiles obtained with the various protease inhibitors, it was confirmed that the partially purified protease belongs to the serine protease type. The activity of partially purified enzyme was enhanced by calcium, magnesium, barium, potassium and manganese ions and strongly inhibited by mercury ion. In addition, the protease showed remarkable stability in the presence of $1 \%$ SDS; 1,3 and $5 \%$ Triton X-100 and $\mathrm{H}_{2} \mathrm{O}_{2}$, which comprise the common bleach-based detergent formulation. The enzyme was found equally efficient to a commercial enzyme Oropon K (one of the commercial enzymes imported into Bangladesh for bating purpose) in bating of animal hide as proved by different comparative qualitative tests such as tensile strength, percent of elongation, stitch tears strength, water vapor permeability, grain crack strength and tongue tear strength tests. In addition, the stability profile ( $\mathrm{pH}$, temperature and surfactants) and blood stain removal data also revealed its suitability for application in detergent industry.
\end{abstract}

Keywords: Alkaline Protease; Bacillus licheniformis MZK05M9 (BlM9); Bating; Characterization; Eco-Friendly.

\section{Introduction}

Proteases are the most valuable enzymes (Kaur et al. 2001) and accounting for more than $65 \%$ of the total industrial enzyme market (Rao et al. 1998, Banik \& Prakash 2004). Alkaline proteases occur widely in plants, animals and microorganisms (Kumar et al. 2008) but proteases from microbial sources are preferred to the enzymes from plant and animal sources since microbial alkaline proteases are extracellular nature and are directly secreted into the fermentation broth by the organism, thus simplifying the downstream processing of the enzyme as compared to the proteases obtained from plant and animals (Arulmani et al. 2007). Microbial proteases can be produced from bacteria, fungi and yeast through submerged and solid state fermentation (Kumar \& Takagi 1999, Anwar \& Saleemuddin 2000, Haki \& Rakshits 2003). In bacteria, protease enzyme is produced mainly by Bacillus licheniformis, $B$. horikoshii, B. sphaericus, B. furmis, B. alcalophilus, B. subtilis (Adinarayana \& Ellaiah 2004).These enzymes are used in the detergent, leather industries, food, pharmaceutical and also have application in silver recovery from photographic plates and in peptide synthesis (Paliwal et al. 1994). The largest application of the proteases is in the laundry detergents, where they help in removing protein-based stains from clothing dur ing washing (Najafi et al. 2005). In leather industry, the protease enzymes are used in soaking, dehairing and bating steps of leather processing (Zambare et al. 2013). In bating process the alkaline protease removes the non-structural proteins from hides and skins which render the leather produce soft, pliable and permeable. In this study, characterization of partially purified protease obtained from a mutant Bacillus licheniformis MZK05M9 (BlM9) and its application in bating step of leather processing, and in washing to remove blood stain from cloth have been described.

\section{Material and methods}

\subsection{Bacterial strain}

Bacillus licheniformis MZK05M9 (BlM9), a mutant strain developed in our laboratory, that produced an alkaline protease was used in the present study. The stock cultures of the strain were maintained as glycerol stocks $(15 \% \mathrm{v} / \mathrm{v})$ and stored at $80^{\circ} \mathrm{C}$. 


\subsection{Enzyme production}

Production of alkaline protease by $B l \mathrm{M} 9$ was carried out in Molasses soya meal medium containing $(\mathrm{g} / \mathrm{l})$ : soybean meal 10 , molasses 5.0, $\mathrm{K}_{2} \mathrm{HPO}_{4} 3.0, \mathrm{MgSO}_{4} .7 \mathrm{H}_{2} \mathrm{O} 0.5, \mathrm{NaCl} 0.5$ and $\mathrm{CaCl}_{2} \cdot 2 \mathrm{H}_{2} \mathrm{O}$ 0.5. Fermentation was performed in a laboratory scale bio-reactor $\left(7\right.$ liter) at $37^{\circ} \mathrm{C}$ and $\mathrm{pH} 7.5$ for $34 \mathrm{hrs}$. The $\mathrm{dO}_{2}$ concentration was maintained at $30 \%$ by cascade control system.

\subsection{Enzyme separation and partial purification}

The fermented culture was centrifuged at $6000 \mathrm{rpm}$ for 15 minutes for solid-liquid separation and the supernatant (crude enzyme) was used for further purification. The proteins from the cell free supernatant were precipitated with ammonium sulfate (60\% saturation). The protein is re-suspended in $0.02 \mathrm{M}$ Tris-HCl buffer, $\mathrm{pH} 7.5$ and dialyzed against same buffer for desalting. The dialyzed fraction was subjected to gel filtration on a Sephadex G-75 column $(1.5 \times 60 \mathrm{~cm})$, which has been equilibrated previously with $25 \mathrm{mM}$ Tris- $\mathrm{HCl}$ buffer, $\mathrm{pH} 7.5$. The same buffer was used to collect the fractions of $1.5 \mathrm{ml}$ at a flow rate of $1 \mathrm{ml} / \mathrm{min}$. Protein concentration and protease activity were determined. Fractions showing protease activities were pooled.

\subsection{Sodium dodecyl sulfate polyacrylamide gel elec- trophoresis (SDS-PAGE)}

SDS-PAGE was carried out using a 4\% (w/v) stacking gel and $10 \%$ (w/v) separating gel as described by Laemmli (1970), under reducing conditions. The sample for SDS-PAGE was prepared by mixing the enzyme with sample buffer in a ratio of 1:1. The mixture was heated at boiling water for 5 minutes. After complete electrophoresis, the gel was transferred into a staining solution of Coomassie Brilliant Blue R-250 for overnight with gentle agitation at room temperature. After staining, the gel was destained using a destaining solution until the background had been satisfactorily removed and protein bands became clear.

\subsection{Protease assay}

Protease activity was determined by modified Kreger \& Lockwood (1981) method with azocasein as a substrate. $400 \mu \mathrm{l}$ of appropriately diluted enzyme was added to $400 \mu 1$ of $1 \%$ azocasein solution in $0.05 \mathrm{M}$ Tris- $\mathrm{HCl}$ buffer $(\mathrm{pH} \mathrm{8.5)}$ and incubated in a water bath at $37^{\circ} \mathrm{C}$ for 60 minutes. The enzyme reaction was stopped by the addition of $135 \mu 1$ of $35 \%$ TCA and then kept at $4{ }^{\circ} \mathrm{C}$ for 15 minutes. The solution was then centrifuged at $13,000 \mathrm{rpm}$ for 10 minutes. In the $750 \mu \mathrm{l}$ of supernatant $750 \mu$ of $1 \mathrm{~N} \mathrm{NaOH}$ solution was added and mixed well. Absorbance was measured at $440 \mathrm{~nm}$ immediately. In control, TCA was added before the incubation. One unit of protease activity was defined as the amount of enzymes that produces an increase in the absorbance of 0.01 under the above assay condition.

\subsection{Protein content determination}

Soluble protein in the culture supernatant was estimated according to the Bradford method (Bradford 1976) using Bovine Serum Albumin (BSA) as a standard. Protein concentration at various steps of purification was estimated by taking absorbance at $595 \mathrm{~nm}$. The specific activity is expressed as units/mg of protein.

\subsection{Characterization of partially purified protease}

\subsubsection{Effect of temperature on enzyme activity and stability}

The optimum temperature for partially purified protease activity was measured by incubating the enzyme with $1 \%(\mathrm{w} / \mathrm{v})$ azocasein as a substrate at various temperatures ranging from $30^{\circ} \mathrm{C}$ to $75^{\circ} \mathrm{C}$ for 60 minutes. The thermostability of the protease was determined by pre-incubating the enzyme in absence and presence of $5 \mathrm{mM}$ of $\mathrm{Ca}^{2+}$ at temperature of $30,40,50,60$, and $70^{\circ} \mathrm{C}$ for 60 minutes following the determination of relative activity under standard assay condition. The untreated enzyme was taken as control.

\subsubsection{Effect of pH on enzyme activity and stability}

The optimum $\mathrm{pH}$ for partially purified protease was determined with $1 \%(\mathrm{w} / \mathrm{v})$ azocasein as the substrate dissolved in different buffers (potassium phosphate, $\mathrm{pH}$ 5 7.5; Tris- $\mathrm{HCl}, \mathrm{pH}$ 8.0 9.5; and glycine- $\mathrm{NaOH}, \mathrm{pH} 10 \sim 11)$. The $\mathrm{pH}$ stability was determined by measuring the relative activity of the enzyme after 60 minutes of pre-incubation in the buffers of various $\mathrm{pH}$ values (5 11) at room temperature.

\subsubsection{Effect of metal ions and enzyme inhibitors}

Effect of various metal ions $\left(\mathrm{Ca}^{2+}, \mathrm{Ba}^{2+}, \mathrm{Cu}^{2+}, \mathrm{Mg}^{2+}, \mathrm{Mn}^{2+}\right.$, $\mathrm{Hg}^{2+}, \mathrm{Na}^{+}, \mathrm{K}^{+}$and $\mathrm{Zn}^{2+}$ ) on the protease activity was studied by pre-incubating the partially purified enzyme at room temperature in a specified ion ( $5 \mathrm{mM}$ final concentration) containing buffer solution for 60 minutes. The enzyme assay was carried out under standard assay condition. The effect of enzyme inhibitors was studied using ethylenediaminetetraacetic acid (EDTA), phenylmethylsulfonyl fluoride (PMSF) and $\beta$ mercaptoethanol. The partially purified enzyme was preincubated for 60 minutes at $45^{\circ} \mathrm{C}$ with each inhibitor ( $5 \mathrm{mM}$ ). The relative activity was measured using azocasein as substrate at $37^{\circ} \mathrm{C}$.

2.7.4. Effect of bleach, surfactants and detergents on enzyme activity

The effect of some surfactant and oxidizing agents (SDS, Tween-80, Triton X-100 and $\mathrm{H}_{2} \mathrm{O}_{2}$ ) at $1 \%, 3 \%$ and $5 \%$ concentration on partially purified enzyme was studied by determining the relative activity of enzyme after pre-incubation for 60 minutes at $37^{\circ} \mathrm{C}$. The activity of enzyme without additive was taken as $100 \%$.

The compatibility of partially purified protease with local laundry detergents was studied using Surf Excel, Wheel, Chaka, Tibet, Jet and Fast Wash. The tap water was used to dilute the detergents to give a final concentration of $7 \mathrm{mg} / \mathrm{ml}$ to simulate washing conditions. The endogenous proteases contained in these detergents were inactivated by incubating the diluted detergents at $65^{\circ} \mathrm{C}$ for 60 minutes prior to the addition of enzyme. Protease was incubated in various detergents solutions for 60 minutes at room temperature and the relative activity was determined under standard assay condition. The enzyme activity of a control (without detergent), incubated under the similar conditions, was taken as $100 \%$.

\subsection{Washing performance test}

For the determination of applicability of protease enzyme as detergent additive clean cotton cloth pieces $(5 \mathrm{~cm} \times 5 \mathrm{~cm})$ were soiled with blood and dried for 7 days at room temperature. The cloth pieces stained with blood were taken in separate flasks. The following three sets were prepared and studied.

1) Flask containing tap water $(50 \mathrm{ml})+$ cloth piece stained with blood.

2) Flask containing tap water $(50 \mathrm{ml})+$ cloth piece stained with blood + Surf Excel $(7 \mathrm{mg} / \mathrm{ml})$. 
3) Flask containing tap water $(50 \mathrm{ml})+$ cloth piece stained with blood + Surf Excel $(7 \mathrm{mg} / \mathrm{ml})+1.5 \mathrm{ml}(902 \mathrm{U})$ of crude enzyme solution.

The above flasks were incubated at room temperature for 30 minutes. After incubation, the cloth pieces were taken out of flasks and rinsed with water and dried. Visual examination was performed and difference was checked. Untreated cloth piece stained with blood were taken as control.

\subsection{Bating activity of the protease}

For determining the bating activity of $B l \mathrm{M} 9$ protease, crude enzyme ( $2 \%$ of hide weight; $100 \mathrm{ml}$ equivalent to $60,100 \mathrm{U}$ $=34,841 \mathrm{LVU}$ for $5 \mathrm{~kg}$ hide) was applied to the cow hide in presence of water. Cow hide (after deliming) emerged in the enzyme preparations were rolled in a drum for about 60 minutes. Then the bubble, cross section, thumb, tensile strength, percent of elongation, stitch tear strength, water vapor permeability, grain crack strength and tongue tear strength tests were performed. In parallel, as a control, a commercial enzyme (Oropon $\mathrm{K})$ as $0.5 \%(\mathrm{w} / \mathrm{w})$ of leather weight was also used in bating experiment.

\section{Results}

\subsection{Protease purification}

The protease produced by Bacillus licheniformis MZK05M9 (BlM9) was partially purified by ammonium sulfate precipitation, dialysis and size exclusion chromatography on Sephadex G-75. The partially purified protein showed a specific activity of $1624 \mathrm{U} / \mathrm{mg}$ and the purification fold was 2.70 (Table 1). SDS-PAGE analysis of purified enzyme showed a molecular mass of about $27.2 \mathrm{kDa}$ (Fig. 1).

Table 1: Purification of Alkaline Protease from $B l \mathrm{M} 9$.

\begin{tabular}{ll|l}
\hline Purification steps & $\begin{array}{l}\text { Specific activity } \\
\text { (U/mg) }\end{array}$ & $\begin{array}{l}\text { Purification } \\
\text { (fold) }\end{array}$ \\
\hline Crude extract & 601 & 1 \\
$\begin{array}{l}\text { Ammonium Sulfate }(60 \%) \\
\text { precipitation }\end{array}$ & 743 & 1.23 \\
$\begin{array}{l}\text { Sephadex G-75 Column } \\
\text { Chromatography }\end{array}$ & 1624 & 2.70 \\
\hline
\end{tabular}

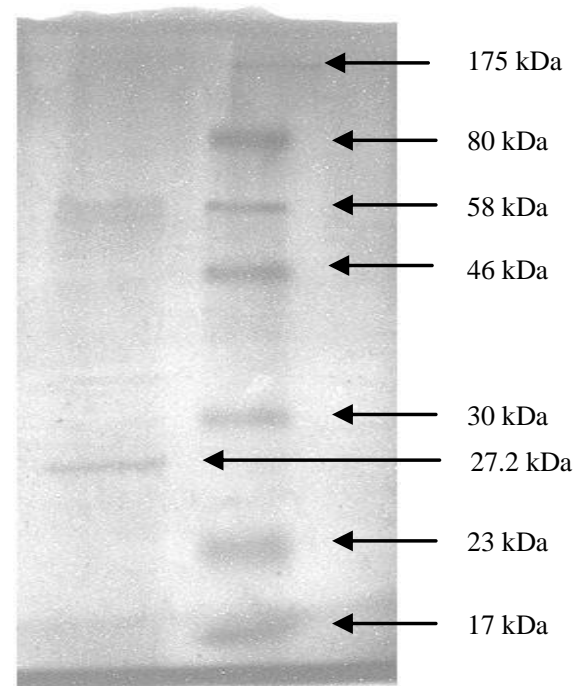

Fig. 1: SDS-PAGE Analysis of Partially Purified Alkaline Protease.

Lane $($ Left $)=$ partially purified enzyme, Lane $($ Right $)=$ Marker.

\subsection{Effect of temperature on enzyme activity and stability}

The enzyme was active in a large temperature range, with an optimum at $55^{\circ} \mathrm{C}$ (Fig. 2). The relative activities at 50 and $60^{\circ} \mathrm{C}$ were about $83 \%$ and $75 \%$, respectively, of that at $55^{\circ} \mathrm{C}$.

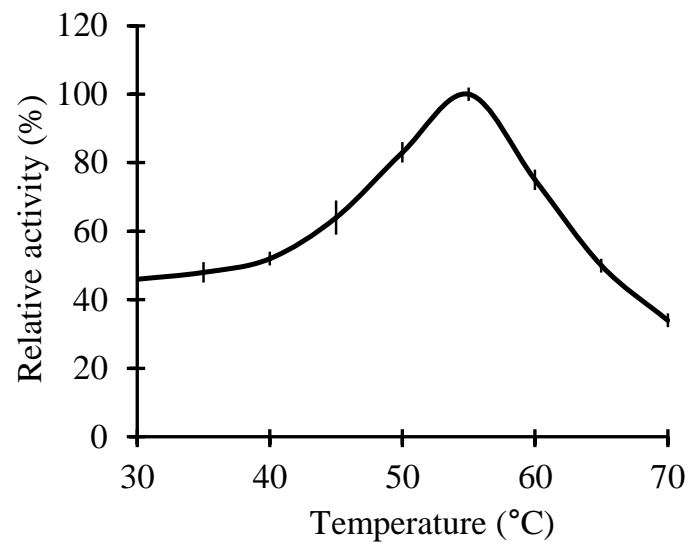

Fig. 2: Temperature Activity of the Protease from BlM9.

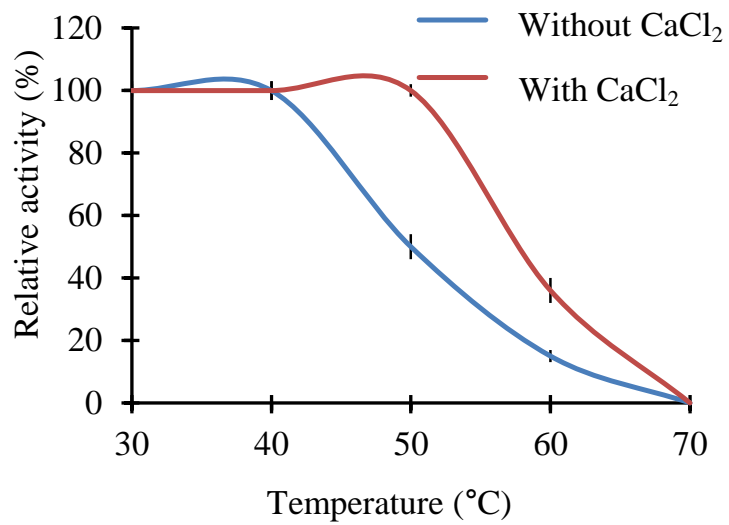

Fig. 3: Thermostability of the Protease from $B l \mathrm{M} 9$.

The purified enzyme showed different temperature stability than its direct activity at various temperatures $\left(30-70^{\circ} \mathrm{C}\right.$ ) (Fig. $3)$. Results indicate that the enzyme was stable at $40^{\circ} \mathrm{C}$ without loss of any activity. Whereas at $50^{\circ} \mathrm{C}$ the relative activity become half $(50 \%)$ of the original activity and at $70^{\circ} \mathrm{C}$ it becomes zero $(0 \%)$. However, addition of $\mathrm{CaCl}_{2}$ stabilizes the enzyme up to $50^{\circ} \mathrm{C}$.

\subsection{Effect of pH on enzyme activity and stability}

The partially purified enzyme was found highly active between $\mathrm{pH} 7.0$ and 9.5 with an optimum at $\mathrm{pH} 8.5$, indicating its alkaline nature. The relative activities at $\mathrm{pH} 6.5$ and 10.0 were about $74 \%$ and $69 \%$, respectively, of that at optimal pH (Fig. 4). The $\mathrm{pH}$ stability profile of alkaline protease showed that the partially purified enzyme was stable between 7.0 and 8.0 but in presence of $\mathrm{CaCl}_{2}$, the enzyme showed stability in wide $\mathrm{pH}$ ranges 6.5-9.0 (Fig. 5). 


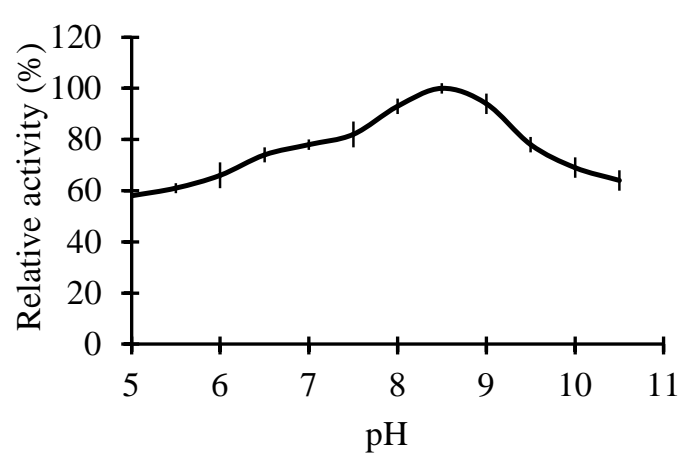

Fig. 4: pH Activity of the Protease from BlM9.

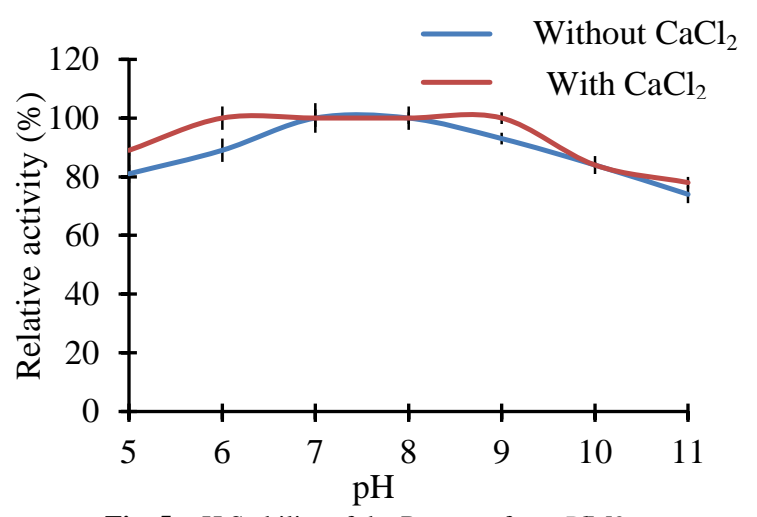

Fig. 5: pH Stability of the Protease from $B l \mathrm{M} 9$.

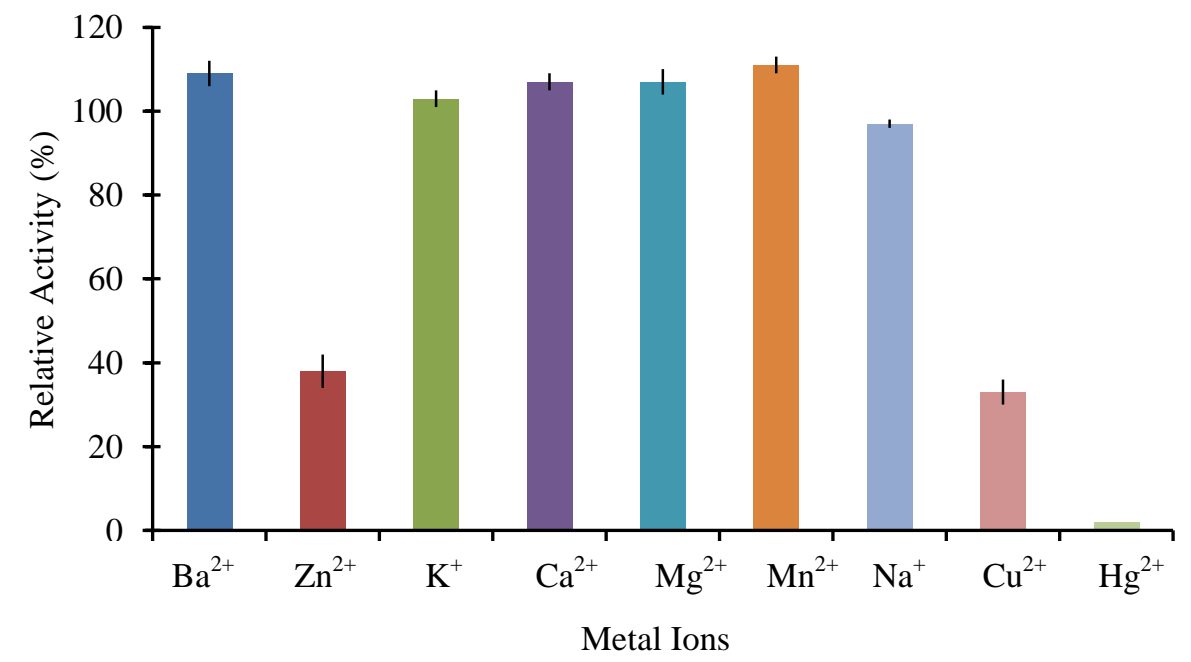

Fig. 6: Effect of Metal Ions on the Protease from $B l \mathrm{M} 9$.

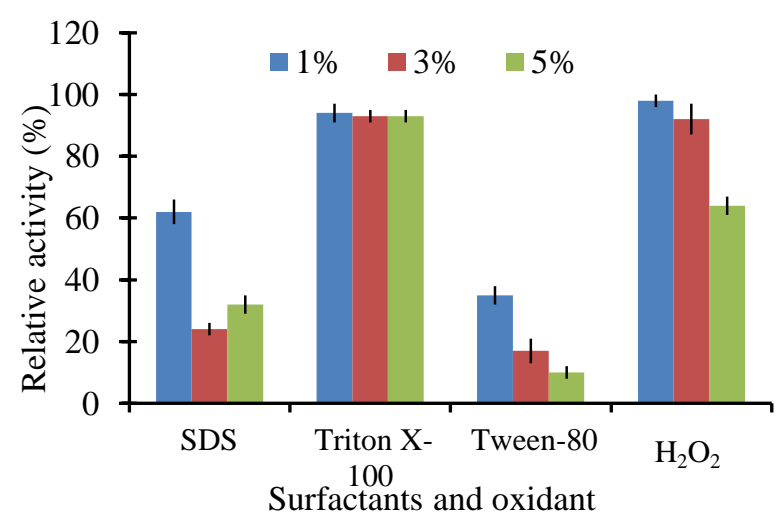

\subsection{Washing performance test}

In case of removing blood stain from cloth, it was observed that the protease enables the removal of blood stain very efficiently in association with detergent (Fig. 8).

Fig. 7: Effect of Surfactants and Oxidant on the Protease. 

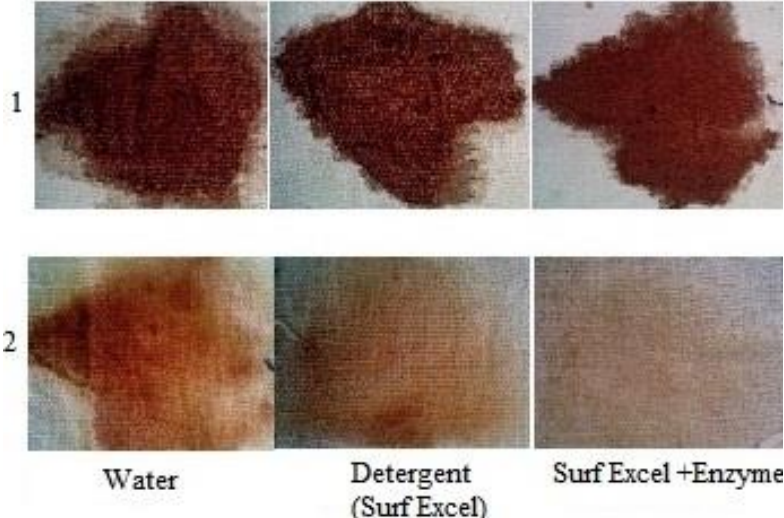

Fig. 8: Washing Performance of $B l \mathrm{M} 9$ Alkaline Protease.

$1=$ Before Treatment, 2 = After Treatment.

\subsection{Bating activity of the protease}

Enzymatic bating in leather manufacturing offers eco-friendly process. For determining the efficiency in bating, $B l \mathrm{M} 9$ protease was compared with a mostly used (in Bangladesh) commercial enzyme Oropon K (TFL, London) in prototype facilities. The results of different tests of the enzyme treated leather ( crushed leather) such as tensile strength, percent of elongation, stitch tear strength, water vapor permeability, grain crack strength (Lastome- ter), and tongue tear strength tests indicated that $B l \mathrm{M} 9$ bate was equally efficient to the commercial bate Oropon $\mathrm{K}$ (Table 2).

Table 2: Different Test Report of Crushed Leather Bated by BlM9 Bate and Commercial Bate.

\begin{tabular}{|c|c|c|c|}
\hline Name of the tests & $\begin{array}{l}0.5 \% \text { com- } \\
\text { mercial bate }\end{array}$ & $\begin{array}{l}2 \% B l \mathrm{M} 9 \\
\text { bate }\end{array}$ & $\begin{array}{l}\text { Standard Val- } \\
\text { ue* }^{*}\end{array}$ \\
\hline Tensile Strength test & $202.49 \mathrm{Kg} / \mathrm{cm}^{2}$ & $\begin{array}{l}254.12 \\
\mathrm{Kg} / \mathrm{cm}^{2}\end{array}$ & $\begin{array}{l}200 \mathrm{Kg} / \mathrm{cm}^{2} \\
\text { (minimum) }\end{array}$ \\
\hline$\%$ of Elongation Test & $44.66 \%$ & $55 \%$ & $\begin{array}{l}80 \% \text { (maxi- } \\
\text { mum) }\end{array}$ \\
\hline $\begin{array}{l}\text { Stitch Tear Strength } \\
\text { Test }\end{array}$ & $121.20 \mathrm{Kg} / \mathrm{cm}$ & $\begin{array}{l}173.07 \\
\mathrm{Kg} / \mathrm{cm}\end{array}$ & $\begin{array}{l}80 \mathrm{Kg} / \mathrm{cm} \\
\text { (minimum) }\end{array}$ \\
\hline $\begin{array}{l}\text { Water Vapor Permea- } \\
\text { bility Test }\end{array}$ & $10.96 \mathrm{mg} / \mathrm{cm}^{2}$ & $\begin{array}{l}11.32 \\
\mathrm{mg} / \mathrm{cm}^{2}\end{array}$ & $\begin{array}{l}10 \mathrm{mg} / \mathrm{cm}^{2} \\
\text { (minimum) }\end{array}$ \\
\hline $\begin{array}{l}\text { Grain Crack Strength } \\
\text { (Lastometer)Test }\end{array}$ & $28 \mathrm{Kg}$ & $20 \mathrm{Kg}$ & $\begin{array}{l}20 \mathrm{Kg} \text { (mini- } \\
\text { mum) }\end{array}$ \\
\hline $\begin{array}{l}\text { Tongue Tear Strength } \\
\text { Test }\end{array}$ & $63.06 \mathrm{Kg} / \mathrm{cm}$ & $\begin{array}{l}55.55 \\
\mathrm{Kg} / \mathrm{cm}\end{array}$ & $\begin{array}{l}45 \mathrm{Kg} / \mathrm{cm} \\
\text { (minimum) }\end{array}$ \\
\hline
\end{tabular}

* (Dutta 1990)

Furthermore, the bubble, thumb and cross section tests of the treated leather (pelt leather) met the requirement of quality bating performance and comparable to the commercial enzyme (Fig. 9).

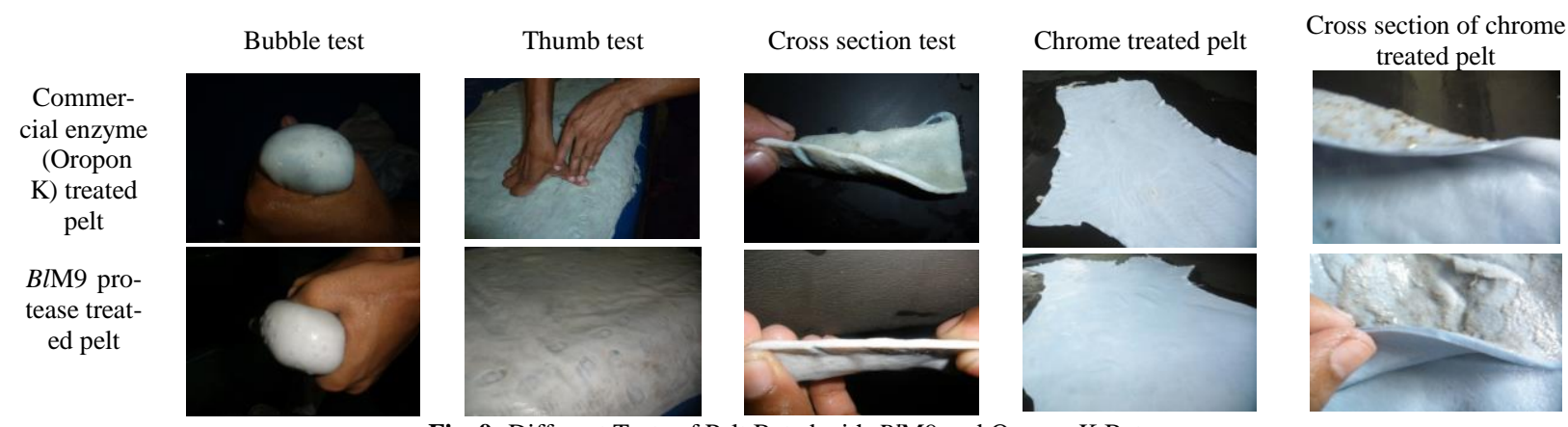

Fig. 9: Different Tests of Pelt Bated with $B l \mathrm{M} 9$ and Oropon K Bate.

\section{Discussion}

The present study has been carried out to partially purify and characterize the alkaline protease and as well as to check its applicability as crude enzyme in detergent and leather processing industries. The partially purified protease showed the molecular mass of $27.2 \mathrm{kDa}$. The optimum $\mathrm{pH}$ for the protease was recorded 8.5, which is lower than the $\mathrm{pH}$ optima values, viz $\mathrm{pH} 11.5(\mathrm{Ku}-$ mar 2002), pH 9.0 (Dhandapani \& Vijayaragavan 1994), pH 10.0 (Gupta et al. 2008), pH 10.5 (Beg \& Gupta 2003) and pH 11.0 (Margesin et al. 1992) reported earlier for other alkaliphilic Bacillus spp. However, the present enzyme with the optimum $\mathrm{pH}$ and stability obtained will suitably comply its application in bating step of leather manufacturing.

The present protease showed an increased activity in the presence of $\mathrm{Ba}^{2+}, \mathrm{K}^{+}, \mathrm{Ca}^{2+}, \mathrm{Mg}^{2+}$ and $\mathrm{Mn}^{2+}$ but lost almost total activity in the presence of $\mathrm{Hg}^{2+}$. Shimogaki et al. (1991) also found the stimulatory effect of $\mathrm{Mn}^{2+}$ on serine alkaline protease. Tsujibo et al. (1990) and Aretz et al. (1989) obtained best results with $\mathrm{Ca}^{2+}$ and $\mathrm{Ba}^{2+}$ with an increase in activity around two-fold. Many alkaline proteases were reported to be inhibited by mercury (Beg \& Gupta 2003) which is harmonious to this study.

Results of sensitivity of partially purified protease to various protease inhibitors showed that strong inhibition (76\% inhibition) was achieved by pre-incubation with PMSF indicating that the enzyme belongs to serine group proteases. However, EDTA, a metalloprotease inhibitor and $\beta$-mercaptoethanol, a cysteine protease inhibitor, slightly inhibited the protease with 29 and $17 \%$ inhibition respectively. Dhandapani \& Vijayaragavan (1994) isolated Bacillus stearothermophilus strain AP-4 producing thermostable alkaline protease that was completely inactivated by PMSF, EDTA and $\beta$-mercaptoethanol and proposed a metal ion-dependent alkaline serine protease.

The feasibility of using alkaline protease as a laundry detergentadditive was evaluated by determining its stability towards some surfactants, oxidant and some laundry detergents available locally. A protease to be used in detergent formulation should be stable in presence of commercial detergents. Protease showed excellent stability and compatibility in the presence of locally available detergents (Surf Excel, Wheel, Tibet, Keya, Jet and Fast Wash) at room temperature. The enzyme retained higher activity $113 \%$ in Tibet and in Fast Wash 98\% after 60 minutes incubation. Uddin et al. (2006) reported that protease from Bacillus licheniformis MZK05 retained 18, 24, 25, 54, 50, 32 and 27\% of its original activity in presence of Jet, Surf Excel, Wheel, Keya, Chaka, Tide and Rain detergents respectively. Singh et al. (2001) reported that SSR 1 protease retained $40-90 \%$ of its activity in presence of local detergents. Hence, the present protease may be suitably used as cleansing aid in detergent formulation like Tibet.

The results obtained using $B l \mathrm{M} 9$ protease as a bating agent in leather processing, in a comparative study with bating agent Oropon $\mathrm{K}$, reflected the unique property of the $B l \mathrm{M} 9$ protease to selectively remove the non-structural proteins (eg. albumin, globulin, elastin etc.) from the hides and skins without affecting the collagen, the main composition of the leather itself. 


\section{Conclusion}

In the present study an alkaline protease from Bacillus licheniformis MZK05M9 was purified, characterized and tested for its efficacy in bating of skins and hides processing in leather industry. The major application of the present protease was found in leather manufacturing industry where the results of different qualitative and quantitative tests suggested its potentiality in bating of skins and hides. The protease showed good stability towards surfactants and oxidants, which are usually used in the formulation of common bleach-based detergents. These results will be a useful basis for commercial production of the alkaline protease.

\section{Acknowledgments}

This work has been partially supported by the financial grant from the Ministry of Education, Government of the People's Republic of Bangladesh. The authors appreciate the contribution of Sabur Ahmed, Fatema -Tuj-Zohra, Md. Ruhul Amin and Syed Rubel Hossain, Institute of Leather Engineering and Technology, University of Dhaka for carrying out bating of pelts using the alkaline enzyme and qualitative analysis of crushed leather.

\section{References}

[1] Adinarayana K \& Ellaiah P (2004), Investigations on alkaline protease production with Bacillus subtilis PE-11 immobilized in calcium alginate gel beads. Process Biochemistry 39, 1331-1339. http://dx.doi.org/10.1016/S0032-9592(03)00263-2.

[2] Anwar A \& Saleemuddin M (2000), Alkaline protease from Spilosomaoblique: potential applications in bioformulations. Biotechnology $\begin{array}{llll}\text { and Applied } & \text { Biochemistry } & \text { 85-89. }\end{array}$ http://dx.doi.org/10.1042/BA19990078.

[3] Aretz W, Koller KP \& Riess G (1989), Proteolytic enzymes from recombinant Streptomyces lividans TK24. FEMS Microbiology Letter 65, 31-36. http://dx.doi.org/10.1111/j.1574-6968.1989.tb03592.x.

[4] Arulmani M, Arumugan P, Kalaichelvan PT, Aparanjini K, Vasanthi K \& Arivuchelvi M (2007), Purification and partial characterization of serine protease from thermostable alkalophilic Bacillus laterosporus AK1. World Journal of Microbiology and Biotechnology 23, 475-481. http://dx.doi.org/10.1007/s11274-006-9249-7.

[5] Banik RM \& Prakash M (2004), Laundry detergent compatibility of the alkaline protease from Bacillus cereus. Microbiological Research 159,135-140. http://dx.doi.org/10.1016/j.micres.2004.01.002.

[6] Beg QK \& Gupta R (2003), Purification and characterization of an oxidation-stable, thiol-dependant serine alkaline protease from Bacillus mojavensis. Enzyme and Microbial Technology 32, 294-304. http://dx.doi.org/10.1016/S0141-0229(02)00293-4.

[7] Bradford MM (1976), A rapid and sensitive method for the quantitation of microgram quantities of protein-dye binding. Applied Biochemistry 72, 80-85.

[8] Dhandapani R \& Vijayaragavan R (1994), Production of a thermophilic, extracellular alkaline protease by Bacillus stearothermophilus AP-4. World Journal of Microbiology and Biotechnology 10, 33-35. http://dx.doi.org/10.1007/BF00357559.

[9] Dutta SS (1990), An introduction to the principles of physical testing of leather, $1^{\text {st }}$ edn. Indian Leather Technologists' Association, Mercantile Buildings, Lalbazar Street, Calcutta.

[10]Gupta A, Joseph B, Mani A \& Thomas G (2008), Biosynthesis and properties of an extracellular thermostable serine alkaline protease from Virgibacillus pantothenticus. World Journal of Microbiology and Biotechnology 24, 237-243. http://dx.doi.org/10.1007/s11274 007-9462-z.

[11] Haki GD \& Rakshit SK (2003), Developments in industrially important thermostable enzymes: a review. Bioresource Technology 89, 17-34. http://dx.doi.org/10.1016/S0960-8524(03)00033-6.

[12]Kaur S, Vohra RM, Kapoor M, Beg QK \& Hoondal GS (2001), Enhanced production and characterization of highly thermostable alkaline protease from Bacillus sp. P-2. World Journal of Microbiology and Biotechnology 17, 125-129. http://dx.doi.org/10.1023/A:1016637528648.

[13] Kreger AS \& Lockwood D (1981), Detection of extracellular toxins produced by Vibrio vulnificus. Infection and Immunity 33, 583-590.

[14]Kumar CG (2002), Purification and characterization of a thermostable alkaline protease from alkalophilic Bacillus pumilus. Letters in Ap- plied Microbiology 34, 13-17. http://dx.doi.org/10.1046/j.1472765x.2002.01044.x.

[15] Kumar CG \& Takagi H (1999), Microbial alkaline proteases: from a bioindustrial viewpoint. Biotechnology Advances 17, 561-594. http://dx.doi.org/10.1016/S0734-9750(99)00027-0.

[16] Kumar PKP, Mathivanan V, Karunakaran M, Renganathan S \& Sreenivasan RS (2008), Studies on the effects of $\mathrm{pH}$ and incubation period on protease production by Bacillus spp. Using groundnut cake and wheat bran. Indian Journal of Science Technology 1, 1-4.

[17]Laemmli UK (1970), Cleavage of structural proteins during the assembly of the head of bacteriophage T4. Nature 227, 680-685. http://dx.doi.org/10.1038/227680a0.

[18] Margesin R, Palma N, Knausedar F \& Schinner F (1992), Purification and characterization of an alkaline protease produced by a psychrotrophic Bacillus sp. Journal of Biotechnology 24, 203-206. http://dx.doi.org/10.1016/0168-1656(92)90124-R.

[19] Najafi MF, Deobagkar D \& Deobagkar D (2005), Potential application of protease isolated from Psedomonas aeruginosa PD100. Electronic Journal of Biotechnology 8, 197-203. http://dx.doi.org/10.2225/vol8-issue2-fulltext-5.

[20] Paliwal N, Singh SP \& Garg SK (1994), Cation induced thermal stability of an alkaline protease from a Bacillus sp. Bioresource Technology 50, 209-211. http://dx.doi.org/10.1016/0960-8524(94)90091-4.

[21]Rao MB, Tanksale AM, Ghatge MS, Deshpande VV (1998), Molecular and biotechnological aspects of microbial proteases. Microbiology and Molecular Biology Reviews 62, 597-635.

[22] Shimogaki H, Takeuchi K, Nishino T, Ohdera M, Kudo T, Ohba K, Iwama M \&Trie M (1991), Purification and properties of a novel surface-active agent and alkaline resistant protease from Bacillus sp. Y. Agricultural and Biological Chemistry 55, 2251-2258. http://dx.doi.org/10.1271/bbb1961.55.2251.

[23] Singh J, Batra N \& Sobti CR (2001), Serine alkaline protease from a newly isolated Bacillus sp. SSR1. Process Biochemistry 36, 781-785. http://dx.doi.org/10.1016/S0032-9592(00)00275-2.

[24] Tsujibo H, Miyamoto K, Hasegawa T \& Inamori Y (1990), Purification and characterization of two types of alkaline serine proteases produced by an alkalophilic Actinomycete. Journal of Applied Bacteriology 69, 520-529. http://dx.doi.org/10.1111/j.13652672.1990.tb01544.x.

[25] Uddin MN, Ilias M, Rahman A \& Hoq MM (2006), Compatibility and Stability of alkaline protease from Bacillus licheniformisMZK-05 with commercial detergent. Bangladesh Journal of Microbiology 23, 19-23.

[26]Zambare VP, Nilegaonkar SS \& Kanekar PP (2013), Protease production and enzymatic soaking of salt-preserved buffalo hides for leather $\begin{array}{llll}\text { processing. } & I I O A B & \text { Letters } & \text { 3, }\end{array}$ http://dx.doi.org/10.5195/iioablett.2013.19. 